\title{
Impact of integrated nutrient management on growth and fruit physical attributes in Cape gooseberry, Physalis peruviana
}

\author{
Niharika Verma, Deepa H Dwivedi, Sachin Kishor and Namrta Singh \\ Department of Applied Plant Science (Horticulture), Babasaheb Bhimrao Ambedkar \\ University, Vidya Vihar Rae Bareli Road Lucknow- 226025, U.P., India
}

\begin{abstract}
Cape gooseberry (Physalis peruviana L.) commonly known as Rasbhari is an important minor tropical Solanaceae fruit crop of India. An experiment was conducted at Horticulture Research Farm, Babasaheb Bhimrao Ambedkar University, Lucknow during winter season 2016-2017, to study the impact of integrated nutrient management on growth and physical attributes of fruits in Cape gooseberry. The experiment comprised six treatments T1 (control)), T2 ((NPK $100 \%$ RDF), T3 (FYM 100\%) T4 (vermicompost 100\%), T5 (50\% NPK + 50\% FYM) and T6 (50\% NPK + 50\% vermicompost) and was laid out in randomized block design with three replications. The observation revealed that the application of 50\% vermincompost+50\% NPK (T6) was better for improvement of plant height $(34.55 \mathrm{~cm})$, stem diameter $(8.4 \mathrm{~cm})$, number of leaves per plant (49.5), number of branches per plant (13.5), leaf length $(8.7 \mathrm{~cm})$ and leaf width $(6.5 \mathrm{~cm})$ along with the fruit physical attributes i.e. fruit weight with husk $(7.0 \mathrm{~g})$, fruit weight without husk (6.7 g), fruit size ( $3.2 \mathrm{~cm}$ equatorial diameter), fruit size ( $3.1 \mathrm{~cm}$ polar diameter), fruit volume (6.9 ml) and fruit specific gravity (1.2) which were found to be increased with the treatment.
\end{abstract}

KEY WORDS: CAPE GOOSEBERRY, RASBHARI, FYM, NPK AND VERMICOMPOST

ARTICLE INFORMATION:

*Corresponding Author: deepahansraj1999@gmail.com Received 12 $2^{\text {th }}$ Oct, 2017

Accepted after revision $27^{\text {th }}$ Dec, 2017

BBRC Print ISSN: 0974-6455

Online ISSN: 2321-4007 CODEN: USA BBRCBA

. Thomson Reuters ISI ESC and Crossref Indexed Journal

NAAS Journal Score 2017: 4.31 Cosmos IF: 4.006

- A Society of Science and Nature Publication, 2017. All rights reserved.

Online Contents Available at: http//www.bbrc.in/

DOI: $10.21786 / \mathrm{bbrc} / 10.4 / 9$ 


\section{INTRODUCTION}

Cape gooseberry (Physalis peruviana L.) of family Solanaceae is an important minor tropical fruit crop of India. It is commonly known as Rasbhari, resembles tomato in shape (Girapu and Kumar, 2006) and is native to the Andes region of South America. It is used in making jam, sauce, pies, puddings, chutneys and ice cream and is eaten fresh in fruit salads and cocktails. It is an excellent source of Vitamin A and C among other nutrients (Chaves et al., 2005). However, its cultivation is restricted to a limited area in India due to low production potential, poorly developed package of practices, etc. Thus, fertilizer application plays an important role in harnessing optimum and good quality fruits in Cape gooseberry. Although chemical fertilizers, particularly nitrogenous and phosphatic fertilizers, contribute a lot in fulfilling the nutrient requirement of plants but continuous use of these fertilizers affects the soil health adversely and deteriorates physicochemical properties of soil. Hence, organic manures may increase soil fertility and thus, the crop production potential possibly by changes in soil physical and chemical properties including nutrient bioavailability, soil structure, water holding capacity, cation exchange capacity, soil $\mathrm{pH}$, microbial community and activity etc. Some organic sources can increase crop yields due to nutrient release during decomposition and mineralization. They may also improve soil physical properties such as moisture retention, bulk density and aeration (Singh et al., 2013, Sharma et al., 2013 and Gond et al., 2017).

Organic materials, besides enhancing $\mathrm{P}$ availability, even supply some $\mathrm{P}$. This is because of their high tissue concentration of $\mathrm{N}$ compared to other nutrients. The objective of the present study was to assess the impact of integrated nutrient management on growth and fruit physical attributes in Cape gooseberry.

\section{MATERIALS AND METHODS}

The experiment was conducted at Horticultural Research Farm, Department of Applied Plant Science, Babasaheb Bhimrao Ambedkar University, Lucknow during November 2016 to May 2017. The soil type of the experimental plot is estimated as being saline having $\mathrm{pH} 8.2$ and low organic carbon (Dwivedi et al., 2012). It is located at $26^{\circ} 50$ 'N latitude and 8052'E longitudes. The experiment comprised six treatments $\mathrm{T}_{1}$ (control)), $\mathrm{T}_{2}$ ((NPK $100 \%$ RDF), $T_{3}$ (FYM) 100\%) $\mathrm{T}_{4}$ (vermicompost 100\%), $\mathrm{T}_{5}$ (50\% $\mathrm{NPK}+50 \% \mathrm{FYM})$ and T6 (50\% NPK + 50\% vermicompost) and was laid out in randomized block design with three replications. Organic manures were incorporated in the experimental plots before transplanting. Standard package of practices for Cape gooseberry (Chattopadhyay, 1996) were followed for the entire crop sea- son. The observation on vegetative and fruit parameters growth was recorded as per standard methods on three plants selected randomly in each treatment. Fruit size (equatorial diameter in $\mathrm{cm}$ ), fruit size (polar diameter $\mathrm{cm})$, fruit volume $(\mathrm{ml})$ and fruit specific gravity were recorded following the methods described by (Rangna 1986) taking five fruits selected randomly from fruits harvested from three plants from each replication. The observed data were analyzed statistically using analysis of variance as formulated at 5\% level of significance (Sahu and Das, 2014).

\section{RESULTS AND DISCUSSION}

The plant height and stem diameter increased significantly by application of organic and inorganic fertilizers as compared to control (Table.1). The maximum plant height $(34.5 \mathrm{~cm})$, stem diameter $(8.4 \mathrm{~cm})$, number of leaves (49.5) per plant, number of branches (13.5) per plant, leaf length $(8.7 \mathrm{~cm})$ and leaf width $(6.5 \mathrm{~cm})$ were recorded in plants treated with 50\% vermicompost and 50\% NPK $\left(\mathrm{T}_{6}\right)$ followed by 50\% NPK+ 50\% FYM $\left(\mathrm{T}_{5}\right)$. Vermicompost has high microbial activity due to presence of fungi, bacteria and actinomycetes (Tomati, et al., 1988) and these microbes are reported to produce plant growth regulators (PGRs) such as auxins, gibberellins, cytokinins, ethylene and abcisic acid (Frankenberger and Arshad, 1995).

Syntheses of these plant growth hormones are known to regulate growth process which affect plant (Singh and Singh, 2009) viz, number of leaves, leaf length, leaf width and leaf area which may be due to the cell division caused by cytokinins. $\mathrm{N}$ being a constituent of protein and chlorophyll plays a vital role in photosynthesis. It enhances accumulation of carbohydrates which, in turn, increase growth of plants, while phosphorus is known to promote cell division as well as photosynthetic activity and flowering (Mahmoud and Amara, 2000). Vermicompost and FYM both provide high amount of $\mathrm{N}(148 \mathrm{~kg} /$ ha) as compared to other organic sources (Dwivedi et al., 2015). Higher nutrient availability and increased nitrogen from organic manures influence in mobilization of the nutrients upon addition of the compost which is further enhanced physical, chemical and biological properties of the soil.

The fruit weight with husk (7.0 g), fruit weight without husk $(6.7 \mathrm{~g})$, fruit size (equatorial diameter $3.2 \mathrm{~cm}$ and polar diameter $3.1 \mathrm{~cm})$, fruit volume $(6.9 \mathrm{ml})$ and fruit specific gravity (1.2) were recorded highest by the application of 50\% vermicompost and 50\% NPK $\left(\mathrm{T}_{6}\right)$ followed by treatment comprising of 50\% NPK+ 50\% FYM $\left(\mathrm{T}_{5}\right)$ as shown in Table 2. Similar results were obtained by (Yadav et al., 2010 and Shukla et al., 2009) in tomato. This increase in fruit size and weight during the present investigation might be due to the increase in photosyn- 


\begin{tabular}{|l|l|l|l|l|l|l|}
\hline \multicolumn{6}{|l|}{ Table 1. Improving vegetative growth trough integrated nutrient management in Cape gooseberry } \\
\hline Treatment & $\begin{array}{l}\text { Plant } \\
\text { height }(\mathrm{cm})\end{array}$ & $\begin{array}{l}\text { Stem diameter } \\
(\mathrm{cm})\end{array}$ & $\begin{array}{l}\text { Number of } \\
\text { leaves/plant }\end{array}$ & $\begin{array}{l}\text { Number of } \\
\text { branches/plant }\end{array}$ & $\begin{array}{l}\text { Leaf length } \\
(\mathrm{cm})\end{array}$ & $\begin{array}{l}\text { Leaf width } \\
(\mathrm{cm})\end{array}$ \\
\hline $\mathrm{T}_{1}$ (Control) & 26.8 & 5.1 & 37.5 & 10.5 & 6.5 & 6.5 \\
\hline $\mathrm{T}_{2}$ (RDF 100\%) & 28.9 & 5.4 & 38.9 & 12.1 & 6.9 & 5.2 \\
\hline $\mathrm{T}_{3}$ (FYM 100\%) & 34.5 & 6.0 & 40.1 & 10.9 & 7.7 & 5.5 \\
\hline $\mathrm{T}_{4}$ (Vermicompost 100 \%) & 32.6 & 5.6 & 42.4 & 10.9 & 7.4 & 5.2 \\
\hline $\mathrm{T}_{5}(50 \%$ NPK+FYM 50\%) & 32.2 & 8.1 & 48.0 & 12.8 & 8.1 & 6.0 \\
\hline $\begin{array}{l}\mathrm{T}_{6}(50 \% \text { vermincompost+50\% } \\
\text { NPK) }\end{array}$ & 34.5 & 8.4 & 49.5 & 13.5 & 8.7 & 6.5 \\
\hline $\mathrm{SE}(\mathrm{m}) \pm$ & 0.45 & 0.39 & 0.65 & 0.36 & 0.23 & 0.22 \\
\hline $\mathrm{CD}(\mathrm{P}=0.05)$ & 1.38 & 1.19 & 1.99 & 1.11 & 0.72 & 0.68 \\
\hline
\end{tabular}

\begin{tabular}{|l|l|l|l|l|l|l|}
\hline \multicolumn{2}{|l|}{ Table 2. Improving fruit growth trough integrated nutrient management in Cape gooseberry } \\
\hline Treatment & $\begin{array}{l}\text { Fruit weight } \\
\text { with husk (g) }\end{array}$ & $\begin{array}{l}\text { Fruit weight } \\
\text { without } \\
\text { husk (g) }\end{array}$ & $\begin{array}{l}\text { Fruit Size } \\
\text { (equatorial } \\
\text { diameter in cm) }\end{array}$ & $\begin{array}{l}\text { Fruit Size } \\
\text { (polar } \\
\text { diameter cm) }\end{array}$ & $\begin{array}{l}\text { Fruit } \\
\text { volume } \\
\text { (ml) }\end{array}$ & $\begin{array}{l}\text { Fruit } \\
\text { specific } \\
\text { gravity }\end{array}$ \\
\hline $\mathrm{T}_{1}$ (Control) & 4.5 & 3.9 & 1.7 & 1.9 & 4.4 & 0.9 \\
\hline $\mathrm{T}_{2}$ (RDF 100\%) & 6.3 & 4.7 & 2.4 & 2.0 & 5.3 & 1.0 \\
\hline $\mathrm{T}_{3}$ (FYM 100\%) & 5.4 & 4.6 & 2.9 & 2.1 & 5.9 & 1.1 \\
\hline $\mathrm{T}_{4}$ (Vermicompost 100 \%) & 6.6 & 5.4 & 2.7 & 2.4 & 5.6 & 1.1 \\
\hline $\mathrm{T}_{5}(50 \%$ NPK+FYM 50\%) & 6.1 & 5.7 & 3.0 & 2.8 & 6.1 & 1.1 \\
\hline $\mathrm{T}_{6}(50 \%$ vermincompost+50\% NPK) & 7.0 & 6.7 & 3.2 & 3.1 & 6.9 & 1.2 \\
\hline $\mathrm{SE}(\mathrm{m}) \pm$ & 0.44 & 0.42 & 0.14 & 0.11 & 1.40 & 0.17 \\
\hline $\mathrm{CD}(\mathrm{P}=0.05)$ & 1.34 & 1.28 & 0.42 & 0.35 & 0.46 & 0.08 \\
\hline
\end{tabular}

thetic activity of plants fertilized with vermicompost, azotobacter and inorganic fertilizer, which in turn might have favored an increased accumulation of dry matter. Fruit size, weight and berry volume are highly correlated with dry matter content and application of organic and inorganic fertilizers and might have balance the level of hormone and nitrogen fixers known for accumulation of dry matter and their translocation (Kachot et al., 2001). Similar results were obtained by (Yadav et $a l$., 2010 and Shukla et al., 2009) in tomato.

\section{REFERENCES}

Chattopadhay, T. K. (1996). A Text Book on Pomology (tropical fruits) Vol. II Kalyani Publishers.

Chaves, A. C., Schuch, M. W. and Erig, A. C. (2005). In Vitro Establishment and Multiplication of Physalis peuviana L. Scientia of Agritechnology. 29: 1281-1287.
Dwivedi, D. H., Lata, R., Ram, R. B. and Babu, M. (2012). Effect of Bio- fertilizer and Organic Manure on Yield and Quality of 'Red Fleshed' Guava. Acta Hort. 933: 239-244.

Dwivedi, D. H., Singh, S., Singh, N and Kumar, P. (2015). Effect of Plant Bio-regulator and Chemical Treatment on Germination of Papaya (Carica papaya L.) cv. Pusa Nanha. Progressive Horticulture. 47 (2): 250-552.

Frankenberger, Jr. W.T. and Arshad, M. (1995). Phytohormones in Soils: Microbial Production and Function. Marcel and Decker, New York. 503.

Girapu, R. K. and Kumar, A. (2006). Influence of Nitrogen and Spacing on Growth, Yield and Economics of Cape gooseberry. Proceedings of national symposium on production, utilization and export of underutilized fruits. West Bengal.

Gond, M., Dwivedi, D. H., and Singh. N. (2017). Performance of Cape Gooseberry (Physalis peruviana L.) Under Different Spacing and Organic Manures. The Bioscan. 12 (1): 377380. 
Kachot, N. A., Malvia, D. D., Solanki, R. M. and Sagrka, B. K. (2001). Integrated Nutrient Management in Rainy Season Groundnut. I. J. Agron. 46: 516-522.

Mahmoud, H. A. F. and Amara, M. A. T. (2000). Response of Tomato to Biological and Mineral Fertilizers Under Calcareous Soil Conditions. Bull. Fac. Agri. Univ. Cairo. 51:151174.

Rangna, S. (1986). Handbook of Analysis and Quality Control for Fruit and Vegetable Products. Tata McGraw Hill Publication Company Limited, New Delhi.

Sahu, P. K. and Das. A. K. (2014). Agriculture and applied statistics. Kalyani Pub, Vol. 2: 170-174.

Sharma, A., Wali, V. K., Bakshi, P. and Jasrotia, A. (2013). Effect of Organic and Inorganic Fertilizers on Quality and Shelf Life of Guava (Psidium guajava L.) cv. Sardar. The Bioscan. 8(4): 1247-1250.
Shukla, Y. R., Thakur, A. K. and Joshi, A. (2009). Effect of inorganic and biofertilizers on yield and horticultural traits of tomato. I. J. Hort. 66(2): 285-287 (2009).

Singh, A. and Singh, J. N. (2009). Effect of Biofertilizers and Bioregulators on Growth, Yield and Nutrient Status of Strawberry cv. Sweet Charlie. Indian Journal of Horticulture. 66 (2): 220-224.

Singh, A., Gulati, I. J., and Chopra, R. (2013). Effect of Various Fertigation Schedules and Organic Manures on Tomato (Lycopersicon esculentum Mill.) Yield under Arid Condition. The Bioscan. 8(4): 1261-1264

Tomati, U., Grappelli, A. and Galli, E. (1988). The Hormone Like Effect of Earthworm Casts on Plant Growth. Biol. Fertil. Soils. 5: 288-294.

Yadav, S. K., Khokhar, U. U. and Yadav, R. P. (2010). Integrated Nutrient Management for Strawberry Cultivation. Indian Journal of Horticulture. 67 (4): 445-49. 